\title{
NEW CHROMOSOME NUMBERS IN PILOCARPUS VAHL (RUTACEAE) ${ }^{1}$
}

\author{
Ladislau A. Skorupa ${ }^{2}$
}

Recebido em 28/01/1999. Aceito em 23/11/1999

\begin{abstract}
RESUMO - (Novos números cromossômicos em Pilocarpus Vahl (Rutaceae). Contagens cromossômicas em oito espécies de Pilocarpus Vahl (Rutaceae) do Brasil são relatadas pela primeira vez. Os números cromossômicos foram determinados a partir de células de ponta de raiz de mudas mantidas em casa-devegetação e obtidas em expedições de coleta. $\mathrm{O}$ método Feulgen foi empregado para a coloração dos cromossomos. O pré-tratamento das pontas de raiz foi feito em solução saturada de alfa-bromonaftaleno por duas horas à temperatura ambiente $\left(20-25^{\circ} \mathrm{C}\right)$. Foram identificados os números diplóides $2 \mathrm{n}=44 \mathrm{e}$ $2 \mathrm{n}=88$. Os resultados sugerem a ocorrência de tetraploidia em $P$. spicatus $\mathrm{St}$.-Hil. e em $P$. carajaensis Skorupa, e um possível número básico $\mathrm{x}=22$ para o gênero Pilocarpus.
\end{abstract}

Palavras-chave - Pilocarpus, Rutaceae, Cusparieae, citogenética, poliploidia

\begin{abstract}
New Chromosome numbers in Pilocarpus Vahl (Rutaceae). Chromosome counts for eight species of Pilocarpus Vahl (Rutaceae) a native of Brazil are reported for the first time. Chromosome numbers were determined from mitotic root tip cells of seedlings derived from field collections and grown in the greenhouse. Feulgen staining was used. Initial pre-treatment of root tips was done by using a saturated aqueous solution of alpha-bromonapthalene for two hours at room temperature $\left(20-25^{\circ} \mathrm{C}\right)$. Chromosome numbers of $2 n=44$ and $2 n=88$ were determined for the examined taxa. The present results suggest the occurrence of tetraploidy in $P$. spicatus St.-Hil. and $P$. carajaensis Skorupa, and a possible basic number $\mathrm{x}=22$ to the genus Pilocarpus.
\end{abstract}

Key words - Pilocarpus, Rutaceae, Cusparieae, cytology, polyploidy

\section{Introduction}

Pilocarpus (Rutaceae) is a neotropical genus of shrubs or small trees and comprises 16 species (Skorupa 1996). It occurs from Southern Mexico to Southern South America. The entire genus is of interest due to the occurrence of pilocarpine, an alkaloid widely used in ophthalmology, especially in the treatment of glaucoma (Lewis \& Elvin-Lewis 1977). This alkaloid is found in the leaves of some species, the most important of which in terms of alkaloid production, being $P$. microphyllus Stapf ex Wardl. (Trease \& Evans 1983).

Rutaceae chromosome numbers are relatively scarce and scattered in the literature. 
Stace et al. (1993) state that only 73 out of 150 genera of Rutaceae (ca. 49\%) and approximately 250 out of ca. 1.800 species of the family (14\%) have some information on their chromosome number. Specifically in Pilocarpinae, a subtribe of Cusparieae, with four genera (Pilocarpus, Metrodorea, Esenbeckia and Raulinoa), only Pilocarpus and Esenbeckia have one species in which the chromosome number was determined. Indeed, Pilocarpus chromosome numbers are found in Honsell (1954), Kaastra (1978), Guerra (1984) and Pagliarini \& Pereira (1992), when dealing with $P$. pennatifolius.

The purpose of this paper is to present new chromosome numbers for Pilocarpus as a contribution towards a better knowledge of the genus.

\section{Material and methods}

The eight Pilocarpus species, including their diploid chromosome numbers and collecting sites are given in Tab. 1. Chromosome numbers were determined from mitotic root tips cells of seedlings derived from field collections and grown in the greenhouse at Cenargen/ Embrapa, Brasília, Brazil. Feulgen staining was used (Löve \& Löve 1975). A pre-treatment of root tips was done by using a saturated aqueous solution of alpha-bromonapthalene for two hours at room temperature $\left(20-25^{\circ} \mathrm{C}\right)$. Root tips were then transferred to ethanol : acetic acid solution (3:1) for $24 \mathrm{~h}$ and rinsed three times in $95 \%$ ethanol. Root tips were hydrolyzed in $1 \mathrm{~N} \mathrm{HCl}$ solution for $12 \mathrm{~min}$. at $60^{\circ} \mathrm{C}$, followed by exposure to a $2 \%$ pectinase aqueous solution for $45 \mathrm{~min}$.

Voucher herbarium specimens were deposited in the herbarium of Cenargen (CEN).

\section{Results and discussion}

Two chromosome numbers were found among the taxa (Tab. 1). Of the eight species, six showed $2 n=44$, while two $2 n=88$. Figures 1 4 show mitotic cells in metaphase from three Pilocarpus species. Most of the chromosomes are meta- or submetacentric and have ca. $3 \mu \mathrm{m}$.

Previous chromosome counts for $P$. pennatifolius are found in Honsell (1954), Kaastra (1978), Guerra (1984) and Pagliarini \& Pereira (1992). All authors found $2 n=44$, except Honsell (1954) who reported $2 \mathrm{n}=36$. Considering the results reported here and also the pertaining literature, it seems that Honsell's report $(2 n=36)$ is not correct, as already

Table 1. Taxa analyzed, chromosome numbers, collecting sites and herbarium vouchers of the Pilocarpus species examined.

\begin{tabular}{llll}
\hline Taxa & 2n & Locality, State $^{*}$ & Voucher \\
\hline P. carajaensis Skorupa & 88 & Parauapebas, PA & Skorupa \& Elzamar 996 \\
P. giganteus Engl. & 44 & Cubatão, SP & Skorupa \& Pompéia 981 \\
P. grandiflorus Engl. & 44 & Ilhéus, BA & Skorupa 1014 \\
P. microphyllus Stapf ex Wardl. & 44 & Açailândia, MA & Vieira et al. 850 \\
P. microphyllus Stapf ex Wardl. & 44 & Dr. Eliseu, PA & Vieira et al. 855 \\
P. pauciflorus St.-Hil. ssp. clavatus & 44 & Itapetinga, BA & Skorupa et al. 991 \\
P. spicatus St.-Hil. ssp. spicatus var. spicatus & 88 & Colatina, ES & Skorupa et al. 912 \\
P. spicatus St.-Hil. ssp. spicatus var. lealii & 88 & Valença, BA & Skorupa et al. 987 \\
$\quad$ Machado) Kaastra & & & \\
P. spicatus St.-Hil. ssp. aracatensis Kaastra & 88 & Pacatuba, CE & Skorupa et al. 1003 \\
P. spicatus St.-Hil. ssp. longeracemosus & 88 & Seabra, BA & Skorupa 1008 \\
$\quad$ Mart. ex Engl.) Kaastra & & & \\
P. sulcatus Skorupa & 44 & Tanque Novo, BA & Skorupa 1012 \\
P. trachylophus Holmes & 44 & Tanque Novo, BA & Skorupa 1010 \\
\hline
\end{tabular}

*Brazilian States: BA=Bahia, CE=Ceará, ES=Espírito Santo, MA=Maranhão, PA=Pará, SP=São Paulo 


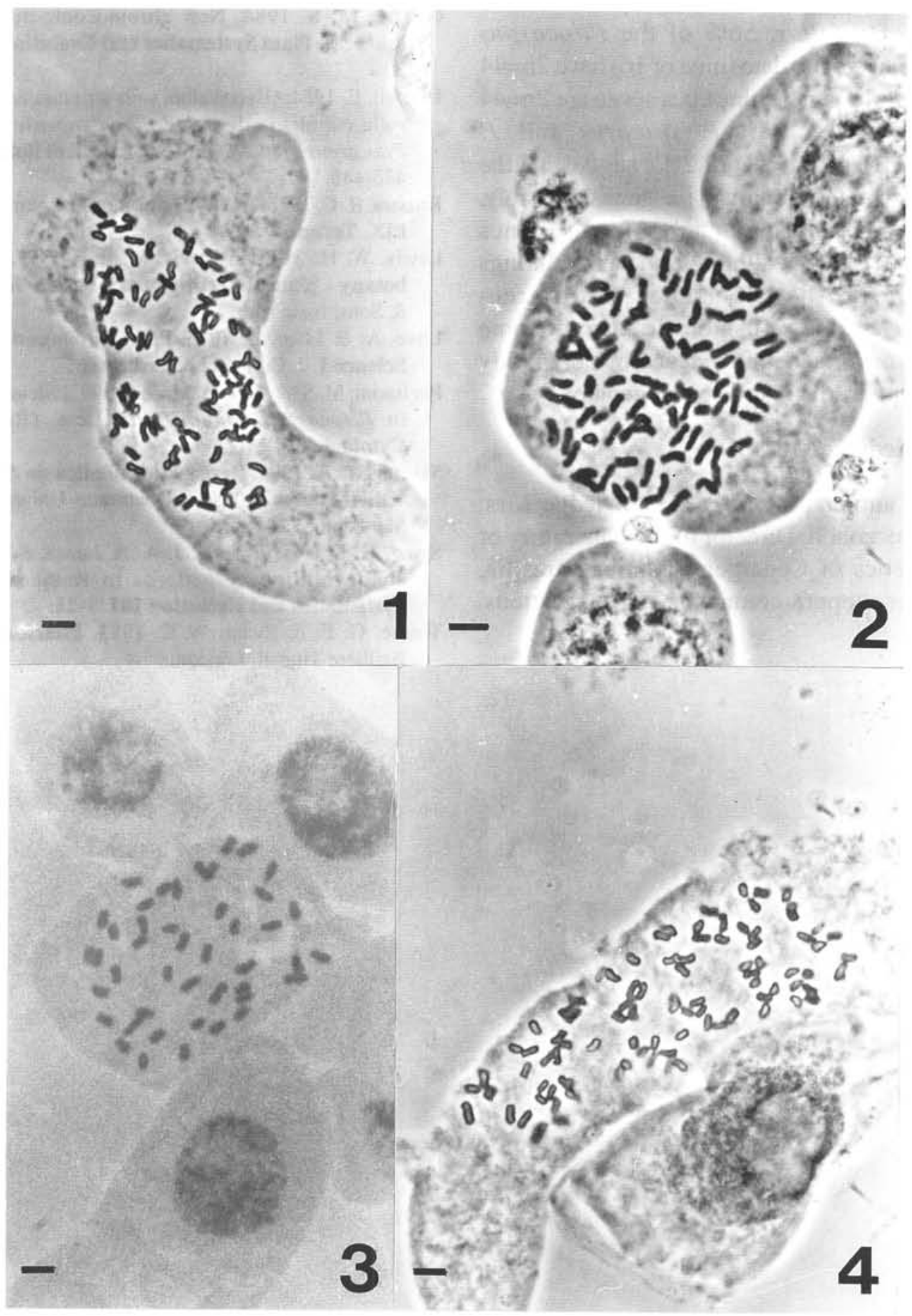

Figures 1-4. Chromosomes in Pilocarpus. 1.P. spicatus subsp. aracatensis (Skorupa et al. 1003), 2n=88. 2. P. spicatus subsp. longeracemosus (Skorupa 1008), $2 \mathrm{n}=88.3$. P. microphyllus (Vieira et al. 850 ), $2 \mathrm{n}=44$. 4. P. carajaensis (Skorupa \& Elzamar 996), $2 \mathrm{n}=88$. (bars $=4 \mu \mathrm{m})$. 
suggested by Pagliarini \& Pereira (1992).

Assuming that $2 \mathrm{n}=44$ is the correct number in $P$. pennatifolius, $56 \%$ of the Pilocarpus species analyzed to date (nine of 16 ) have $2 n=44$ or $2 \mathrm{n}=88$. Among the nine taxa, seven are $2 \mathrm{n}=44$ (77.8\%) while two (P. spicatus and $P$. carajaensis) are $2 \mathrm{n}=88(22.2 \%)$, suggesting the occurrence of tetraploidy in the genus. Possibly, the basic chromosome number for the genus Pilocarpus is $\mathrm{x}=22$, although further countings may indicate the occurrence of different numbers. Studies on meiotic chromosome behavior or on genetic evidence of polyploidy could support the results presented here.

\section{Acknowledgements}

The author gratefully acknowledge Mrs. Marisa Pozzobon, Director of the Laboratory of Cytogenetics of Cenargen/Embrapa, Brasília, Brazil, for support, comments and suggestions.

\section{Literature Cited}

Guerra, M. S. 1984. New chromosome numbers in Rutaceae. Plant Systematics and Evolution 146: 1330.

Honsell, E. 1954. Osservazioni sulla struttura dell'ovulo e sulla cariologia di Calodendron capense Thunb. e Pilocarpus pennatifolius Lem. Annali di Botanica 24: 438-448.

Kaastra, R. C. 1978. In: IOPB chromosome number report LIX. Taxon 27: 53

Lewis, W. H. \& Elvin-Lewis, M. P. F. 1977. Medical botany - plants affecting man's health. John Wiley \& Sons, New York.

Löve, A. \& Löve, D. 1975. Plant chromosomes. Plant Science 1. J. Cramer, Leutershausen.

Pagliarini, M. S. \& Pereira, M. A. S. 1992. Meiotic studies in Pilocarpus pennatifolius Lem. (Rutaceae). Cytologia 57: 231-235.

Skorupa, L. A. 1996. Revisão taxonômica de Pilocarpus Vahl (Rutaceae). Tese de Doutorado. Universidade de São Paulo, São Paulo.

Stace, H. M.; Armstrong, J. A. \& James, S. H. 1993. Cytoevolutionary patterns in Rutaceae. Plant Systematics and Evolution 187: 1-28.

Trease, G. E. \& Evans, W. C. 1983. Pharmacognosy. Baillière Tindall, London. 